\title{
Nepal Journal of Epidemiology
}

eISSN 2091-0800

Research Article

Open Access

\section{Prevalence and predisposing factors for self-reported hypertension in Bhutanese adults}

\author{
Kinley Wangdi ${ }^{1,2}$, Tshering Jamtsho ${ }^{3}$
}

\begin{abstract}
:
Background: Bhutan underwent a nutrition transition in the last two decades. Diet has changed from highfibre, high carbohydrate and low-fat diets to food with high sugar, fat, salt and processed foods. This is further compounded by a sedentary lifestyle. This paper aims to determine the national prevalence of hypertension and study the associated correlates in Bhutanese adults.

Materials and Methods: This study used secondary data from the Bhutan National Health Survey 2012 (NHS, 2012) which was a nationwide survey covering all 20 districts in Bhutan. The dependent variable was selfreported hypertension under medication. Multivariable logistic regression was undertaken to identify independent correlates of hypertension.

Results: The national prevalence of hypertension was $17.4 \%(5,408)$. Risk factors for hypertension were female sex, increasing age, occupation of armed forces, manager, technician, service and sales worker, machine operator and monks, diabetes, and feeling worried. Being single was negatively correlated with hypertension. In addition, hypertension is negatively associated with the poverty of the district.

Conclusion: Hypertension was associated with age, being women, occupation with less physical activity, being worried and having diabetes. The preventive measures both at community and healthcare facility-based through cost-effective strategies should target these covariates.
\end{abstract}

Keyword: Bhutan; hypertension; National Health Survey 2012; risk factors

Correspondence: Dr Kinley Wangdi, Research Fellow, Department of Global Health, Research School of Population Health, The Australian National University, Canberra, Australia.

Email: kinley.wangdi@anu.edu.au

Received 4 September 2019/Revised 10 March 2020/Accepted 22 March 2020

Citation: Wangdi K, Jamtsho T. Prevalence and predisposing factors for self-reported hypertension in Bhutanese adults. Nepal J Epidemiol. 2020;10(1); 830-840.

DOI: $10.3126 /$ nje.v10i1.25466

This work is licensed under a Creative Commons Attribution 4.0 International License. 


\section{Introduction}

Globally, around one billion over the age of 25 years were diagnosed with hypertension in 2008 [1]. Hypertension is defined as an increase in systolic blood pressure above 140 $\mathrm{mmHg}$ and/or diastolic blood pressure equal to or above 90 $\mathrm{mmHg}[2,3]$. Its prevalence is more in low and middleincome countries compared to high-income countries [3]. It is responsible for $45 \%$ of deaths due to heart diseases [4].

Hypertension is caused by both modifiable and non-modifiable risk factors [3]. Modifiable predisposing factors include hyperlipidaemia [5], physical inactivity [6], obesity, kidney disease [7], diabetes, high salt intake [8], alcohol consumption [9, 10], and smoking [11]. Age, ethnic background and gender (female) are important non-modifiable risk factors of hypertension [10]. Effective intervention includes early detection and treatment of hypertension, increased physical activity; reduce salt intake, moderate alcohol consumption, and cessation of smoking.

In the last two decades, Bhutan has undergone a marked nutritional transition [12]. This has resulted in increased disposable income levels and change in food habit with more consumption of saturated fat and salt diet from a traditional low-fat and low-salt diet. Furthermore, people engage in sedentary lifestyle with less physical activity [13]. Rapid urbanisation in last two decade resulted in rural-urban migration and $>31 \%$ of Bhutanese now live in urban areas. An earlier study reported a national prevalence of hypertension to be $17.1 \%$ in 2007 [14], while in the capital city Thimphu it was estimated at $26.0 \%$ [15]. However, there is a lack of study on the national prevalence of hypertension and its associated correlates. Therefore, this study aims to determine the prevalence of hypertension and explore the correlates of hypertension in the Bhutanese population. Exploration of such data in Bhutan is anticipated to provide associated correlates for hypertension in a population undergoing the epidemiologic and nutrition transition.

\section{Methodology}

\section{Study design and participants}

A secondary retrospective study was undertaken using the National Health Survey (NHS 2012) data. The Ministry of Health of Bhutan used the Surveillance of non-communicable diseases (STEP) survey guidelines to collect the data in all the 20 districts of Bhutan. The census sample frame for the NHS 2012 was developed using the Population and Housing Census of Bhutan 2005.

\section{Inclusion criteria}

The records of participants above the age of 18 years were extracted from the NHS data for analysis.

\section{Exclusion criteria}

Records with incomplete data were excluded from the final analysis.

\section{Data collection}

The data were obtained from the Ministry of Health data repository. District poverty was obtained from the Bhutan Multidimensional Poverty Index 2012 published online by the National Statistical Bureau (NSB) of Bhutan [16]. The data were then linked to the proportion of hypertension by districts to examine the relationship between hypertension and poverty.

\section{Sample size calculation}

The sample size was calculated for each district using the following formula:

$$
n=\frac{z^{2} p(1-p)(f)(k)}{e^{2}}
$$

Where: $n$ is the required number of households; $z$ is the value of the statistic in a normal distribution for a $95 \%$ confidence interval (this value is 1.96 and for purposes of calculation it is rounded to 2); $p$ is the proportion of households within 1 hour to any health facility; $\mathrm{e}$ is the margin of error in calculating $p$, (was 0.05 for this study); $f$ is the sample design effect, assumed to be 2.0; and $k$ is an anticipated non-response of $5 \%$. A total of 13,600 households were sampled corresponding to 45,635 individuals aged between $10-75$ years.

\section{Outcome variable}

The dependent variable was self-reported hypertension on medication. The participants in this study were the adult population above 18 years. Independent variables were selfreported correlates obtained from the STEPS survey questionnaire.

\section{Independent variable}

Independent variables of interest were age, sex, education level, occupation, urban-rural residence, ever smokers, ever consumed alcohol, vigorous exercise, vegetable servings per day and feeling of worried. This study included all records of participants older than 18 years.

One standard vegetable serving was defined as: (a) 1 cup of raw green leafy vegetable such as spinach, salad greens, etc. (b) $1 / 2$ cup of other vegetables, cooked or chopped, such as carrots, pumpkin, corn, beans, onion, etc., but excluding tubers such as potatoes. A "standard drink" was quantified through the amount of ethanol in standard glasses of beer, fortified wine such as sherry, wine, and spirits (around 8-13 grams). Worried was defined as a feeling of stress resulting in an inability to sleep at night in the last 12 months. Vigorous activity was defined as any activity that increased heart rate/breathing as in lifting heavy loads, or similar to digging a field for 10 minutes. Hypertension was ascertained by recording medications which lower high blood pressure [17]. 
These correlates were based on the published literature from earlier studies [18-20].

\section{Ethical committee approval}

The ethical approval for this study was provided by the Research Ethics Board of Health (REBH), Ministry of Health Bhutan via REBH/Approval/2018/041.

\section{Data management and statistical analysis:}

Bivariate and multivariate logistic regression model was used to identify significant correlates. Exploratory variables with a $\mathrm{p}<0.10$ in a bivariate model were entered into the final multivariate model. A value of $\mathrm{p}<0.05$ was considered significant. A goodness-of-fit test was undertaken to measure the adequacy of the final model. Statistical analysis was done in STATA version 15.1 (Stata Corporation, College Station, TX, USA).

\section{Results}

\section{Characteristics of the study population}

A total of 31,066 participants aged 18-75 years were extracted from the NHS 2012. The mean age of the survey participants was 39.3 years (95\% confidence interval [CI] 39.2, 39.5) and there were $16,731(53.9 \%)$ women. Twenty-six percent of the participants were in 25-34 age group and 24.6\% lived in urban areas. Nearly half of the study population did not have formal education and $<1 \%$ were diploma or certificate level educated. Two-third were married and $59.8 \%$ were farmers. The prevalence of diabetes in the survey was $1.8 \%$. Forty-seven percent and $4.2 \%$ drank alcohol and smoked, respectively. Vegetables were consumed by $41.0 \%$ in a week. Only $1.0 \%$ of participants were always worried. More than $47.4 \%$ of the study participants were involved in the physical activities resulting in increased breathing (Table 1).

Socio-demographic characteristics of hypertensive patients The national prevalence of hypertension was $17.4 \%$ and female constituted $62.3 \%$ of the study population. Nearly $11.4 \%$ of hypertensive patients were $>64$ years. Most $(76.7 \%$ ) hypertensive people lived in rural Bhutan. Married participants and those with no formal education made up $81.5 \%$ and $59.4 \%$ of study participants. Most of the hypertensive patients were farmers, unskilled and clerical workers, $5.7 \%$ has concurrent diabetes, and nearly half-consumed alcohol (48.5\%), 3.3\% were current smokers and $17.1 \%$ ever smoked. Only $3.3 \%$ did consume vegetables in a typical week, while $40.2 \%, 29.2 \%$ and $27.3 \%$ consumed vegetables in 6-7, 4-5 and 1-3 days respectively. More than half of the participants were never worried or felt lonely. Forty-six percent of hypertensive participants engaged in vigorous physical activity (Table 1). The proportion of hypertensive participants ranged from $10.7 \%$ to $22.0 \%$ with Paro, Punakha and Trashigang districts reporting a higher proportion of hypertension (Figure 1). There was a significant negative association between the proportion of hypertension and district poverty level in the Pearson correlation analysis $(r=-0.4831, \mathrm{p}=0.0309)$.

\section{Factors associated with hypertension}

Being female, above 24 years, single and widow, educated up to university or equivalent and non-formal educated, occupation in manager, service and sales worker, machine operator and monk categories, having diabetes, ever smoked, drank alcohol and being worried was associated with hypertension. Eating vegetable servings of 4-5 days per week offered protection against hypertension (Table 2).

After adjusting for other variables, females were $71 \%$ (AOR $=1.71 ; 95 \%$ CI: 1.516-1.929) more odds to report hypertension than the male participants. There was a linear increase in hypertension with an increase in age. Participants in age groups of 25-34, 35-44 years, 45-54, 55-64 and over 64 years reported adjusted odds ratio $(\mathrm{AOR})=1.27$, $(95 \% \mathrm{CI}$ : 1.007-1.605), $\mathrm{AOR}=2.19$ (95\% CI: 1.724-2.781), $\mathrm{AOR}=3.12$ (95\% CI: 2.441-3.986), AOR=3.54 (95\% CI: 2.715-4.616) and $\mathrm{AOR}=5.33(95 \% \mathrm{CI}: 3.938-7.213)$ as compared to participants aged 18-24 years. Being single as compared to married were 25\% (AOR=0.75; 95\% CI: 0.602-0.931) less likely to be hypertensive. Armed forces $(\mathrm{AOR}=1.48 ; 95 \% \mathrm{CI}$ : 1.1131.955), manager $(\mathrm{AOR}=1.95 ; 95 \% \quad \mathrm{CI}: \quad 1.342-2.836)$, technician $(\mathrm{AOR}=1.33 ; 95 \% \mathrm{CI}: 1.008-1.758)$, service and sales worker $(\mathrm{AOR}=1.38 ; 95 \% \mathrm{CI}: 1.154-1.652)$, craft and other trades $(\mathrm{AOR}=1.32 ; 95 \% \mathrm{CI}$ : 1.007-1.722), machine operator $(\mathrm{AOR}=1.31 ; 95 \% \mathrm{CI}: 1.016-1.701)$, and monks $(\mathrm{AOR}=1.67 ; 95 \% \mathrm{CI}: 1.049-2.649)$ and were at risk of hypertension in comparison to farmers. Diabetes was a major risk factor for hypertension; participants with diabetes were nearly 3.5 times more likely to be hypertensive compared to those who were not diabetic $(\mathrm{AOR}=3.46$; 95\% CI: 2.5964.617). Factors relating to psychological well-being were at risk of hypertension, such as feeling worried rarely ( $\mathrm{AOR}=1.33 ; 95 \% \mathrm{CI}: 1.156-1.532)$, sometimes $(\mathrm{AOR}=1.48$; 95\% CI: $1.328-1.660)$ and always $(\mathrm{AOR}=3.56$; 95\% CI: 2.2465.658) as compared to those participants who were never (Figure 2 \& Table 3). The increased probability of hypertension with increasing age with CI $95 \%$ has been shown in Figure 3. 
Table 1: Socio-demographic characteristics of the study population and hypertensive participants

\begin{tabular}{|c|c|c|c|c|}
\hline \multicolumn{2}{|c|}{ Variables } & \multirow{2}{*}{$\begin{array}{l}\text { Total }(\%) \\
16,731(53.9)\end{array}$} & \multirow{2}{*}{$\begin{array}{r}\text { Hypertensive (\%) } \\
3,371(62.3)\end{array}$} & \multirow{2}{*}{$\begin{array}{r}\text { Non-hypertensive (\%) } \\
13,356(52.1)\end{array}$} \\
\hline Gender & Female & & & \\
\hline & Male & $14,335(46.1)$ & $2,037(37.7)$ & $12,291(47.9)$ \\
\hline \multirow[t]{4}{*}{ Age group (years) } & $18-24$ & $6,083(19.6)$ & $442(8.1)$ & $5,636(22.0)$ \\
\hline & $35-44$ & $6,172(19.9)$ & $1,193(22.1)$ & $4,977(19.4)$ \\
\hline & $45-54$ & $5,100(16.4)$ & $1,190(22.0)$ & $3,909(15.2)$ \\
\hline & $55-64$ & $5,650(11.4)$ & $1,520(28.1)$ & $2,639(10.3)$ \\
\hline Urban-rural & Rural & $23,420(75.4)$ & $4,145(76.7)$ & $19,270(75.1)$ \\
\hline \multirow[t]{5}{*}{ Education } & No formal education & $15,666(50.6)$ & $3,205(59.4)$ & $12,458(48.7)$ \\
\hline & Non-Formal Education & $2,560(8.3)$ & $419(7.8)$ & $2,14098.4)$ \\
\hline & Primary school & $3,820(12.3)$ & $667(12.3)$ & $3,153(12.3)$ \\
\hline & High school & $6,260(20.2)$ & $689(12.8)$ & $5,567(21.8)$ \\
\hline & Diploma/Certificate & $275(0.9)$ & $159(3.0)$ & $222(0.9)$ \\
\hline \multirow{2}{*}{ Marital status } & Divorced/Separated & $1,299(4.2)$ & $242(4.5)$ & $1,057(4.1)$ \\
\hline & Widowed & $1,531(4,9)$ & $396(7.3)$ & $1,135(4.4)$ \\
\hline \multirow{5}{*}{ Occupation } & Clerical/farmer /unskilled & $10,061(66.1)$ & $1,564(65.4)$ & $8,494(66.2)$ \\
\hline & Army & $540(3.5)$ & $86(3.6)$ & $454(3.5)$ \\
\hline & Manager and professionals & $1,338(8.8)$ & $202(8.4)$ & $1,137(8.9)$ \\
\hline & Service and sales worker & $3,155(20.7)$ & $508(21.2)$ & $2,646(20.6)$ \\
\hline & Monks & $134(0.9)$ & $32(1.4)$ & $102(0.8)$ \\
\hline \multirow{2}{*}{ Diabetes } & No & $26,132(98.2)$ & $4,474(94.3)$ & $21,649(99.0)$ \\
\hline & Yes & $491(1.8)$ & $272(5.7)$ & $218(1.0)$ \\
\hline \multirow[t]{2}{*}{ Alcohol intake } & No & $16,378(62.7)$ & $2,784(51.5)$ & $13,587(53.0)$ \\
\hline & Yes & $14,681(47.3)$ & $2,622(48.5)$ & $12,056(47.0)$ \\
\hline Smoking now & No & $29,741(95.8)$ & $5,232(96.8)$ & $24,499(95.5)$ \\
\hline \multirow{3}{*}{ Vegetable servings per week } & 1-3 days & $7,788(25.7)$ & $1,447(27.3)$ & $6,340(25.4)$ \\
\hline & 4-5 days & $9,206(30.3)$ & $1,549(29.2)$ & $7,651(30.6)$ \\
\hline & 6-7 days & $12,420(41.0)$ & $2,131(40.2)$ & $10,286(41.1)$ \\
\hline \multirow[t]{4}{*}{ Anxious/Worried } & Never & $18,054(58.2)$ & $2,701(50.0)$ & $15,353(59.9)$ \\
\hline & Rarely & $4,353(14.0)$ & $748(13.8)$ & $3,605(14.1)$ \\
\hline & Sometimes & $8,311(26.8)$ & $1,849(34.2)$ & $6,462(25.2)$ \\
\hline & Always & $317(1.0)$ & $107(2.0)$ & $210(0.8)$ \\
\hline \multirow[t]{4}{*}{ Felt lonely } & Never & $19,927(64.2)$ & $3,045(56.3)$ & $16,882(65.9)$ \\
\hline & Rarely & $4,038(13.0)$ & $744(13.8)$ & $3,294(12.9)$ \\
\hline & Sometimes & $6,694(21.6)$ & $1,506(27.9)$ & $5,188(20.2)$ \\
\hline & Always & $380(1.2)$ & $112(2.0)$ & $268(1.0)$ \\
\hline \multirow{2}{*}{ Sports } & No & $26,199(84.4)$ & $4,864(90.0)$ & $21,335(83.2)$ \\
\hline & Yes & 4,849 (15.6) & $543(10.0)$ & $4,306(16.8)$ \\
\hline Walk or bike & No & $9,091(29.3)$ & $3,735(69.1)$ & $7,418(28.9)$ \\
\hline & Yes & $21,952(70.7)$ & $1,673(30.9)$ & $18,217(71.1)$ \\
\hline Vigorous activities & No & $16,328(52.6)$ & $2,900(53.6)$ & $13,428(52.4)$ \\
\hline & Yes & $14,721(47.4)$ & $2,507(46.4)$ & $12,215(47.6)$ \\
\hline
\end{tabular}


Table 2: Bivariate logistic regression analysis with the correlates of hypertension

Variable

\begin{tabular}{|c|c|c|c|c|}
\hline & \\
\hline & & OR & $95 \% \mathrm{CI}$ & p-value \\
\hline \multirow{2}{*}{ Sex } & Male & Ref & & \\
\hline & Female & 1.52 & $1.434,1.617$ & $<0.001$ \\
\hline \multirow[t]{6}{*}{ Age group } & $18-24$ & Ref & & \\
\hline & $25-34$ & 1.94 & $1.724,2.175$ & $<0.001$ \\
\hline & $35-44$ & 3.06 & $2.722,3.431$ & $<0.001$ \\
\hline & $45-54$ & 3.88 & $3.454,4.361$ & $<0.001$ \\
\hline & $55-64$ & 4.37 & $3.863,4.938$ & $<0.001$ \\
\hline & $65+$ & 5.27 & $4.600,6.025$ & $<0.001$ \\
\hline \multirow[t]{4}{*}{ Marital status } & Married & Ref & & \\
\hline & Single & 0.32 & $0.282,0.353$ & $<0.001$ \\
\hline & Divorce/separated & 0.97 & $0.838,1.116$ & 0.648 \\
\hline & Widow & 1.47 & $1.305,1.656$ & $<0.001$ \\
\hline \multirow[t]{7}{*}{ Education } & No education & Ref & & \\
\hline & Primary & 0.82 & $0.749,0.901$ & $<0.001$ \\
\hline & High & 0.48 & $0.440,0.525$ & $<0.001$ \\
\hline & University or equivalent & 0.46 & $0.391,0.548$ & $<0.001$ \\
\hline & Diploma/certificate & 0.93 & $0.686,1.256$ & 0.629 \\
\hline & Monastic education & 1.11 & $0.941,1.302$ & 0.219 \\
\hline & NFE & 0.76 & $0.681,0.852$ & $<0.001$ \\
\hline \multirow[t]{10}{*}{ Occupation } & Farmers & Ref & & \\
\hline & Army & 1.01 & $0.794,1.277$ & 0.956 \\
\hline & Managers & 1.53 & $1.116,2.090$ & 0.008 \\
\hline & Professionals & 0.84 & $0.699,1.004$ & 0.055 \\
\hline & Technicians & 0.86 & $0.688,1.081$ & 0.199 \\
\hline & Clerical & 0.78 & $0.544,1.119$ & 0.177 \\
\hline & Service and sales workers & 1.16 & $1.016,1.321$ & 0.028 \\
\hline & Other trades & 1.02 & $0.805,1.299$ & 0.855 \\
\hline & Machine operators & 0.73 & $0.582,0.914$ & 0.006 \\
\hline & Monks & 1.7 & $1.140,2.534$ & 0.009 \\
\hline \multirow{2}{*}{ Urban-rural } & Rural & Ref & & \\
\hline & Urban & 0.95 & $0.889,1.017$ & 0.142 \\
\hline \multirow[t]{2}{*}{ Diabetes } & No & Ref & & \\
\hline & Yes & 6.04 & $5.038,7.235$ & $<0.001$ \\
\hline \multirow[t]{2}{*}{ Ever smoked } & No & Ref & & \\
\hline & Yes & 1.09 & $1.009,1.181$ & 0.028 \\
\hline \multirow[t]{2}{*}{ Ever drank alcohol } & No & Ref & & \\
\hline & Yes & 1.06 & $1.001,1.126$ & 0.047 \\
\hline \multirow[t]{2}{*}{ Vigorous exercise } & No & Ref & & \\
\hline & Yes & 0.95 & $0.896,1.008$ & 0.89 \\
\hline \multirow[t]{4}{*}{ Vegetable servings days per week } & 0 & Ref & & \\
\hline & $1-3$ & 0.93 & $0.784,1.110$ & 0.433 \\
\hline & $4-5$ & 0.83 & $0.696,0.984$ & 0.032 \\
\hline & $6-7$ & 0.85 & $0.714,1.005$ & 0.056 \\
\hline \multirow[t]{4}{*}{ Worried } & Never & Ref & & \\
\hline & Rarely & 1.18 & $1.079,1.288$ & $<0.001$ \\
\hline & Sometimes & 1.63 & $1.523,1.738$ & $<0.001$ \\
\hline & Always & 2.92 & $2.308,3.698$ & $<0.001$ \\
\hline
\end{tabular}

Table 3: Multivariate logistic regression analysis with risk factors for hypertension

\begin{tabular}{lcccc} 
& Variables & & \multicolumn{2}{c}{$\begin{array}{c}\text { Adjusted Correlates } \\
95 \% \text { CI }\end{array}$} \\
Sex & Male & OR & P value \\
Age group & Women & Ref & $1.516,1.929$ & $<0.001$ \\
& $18-24$ & 1.71 & $1.007,1.605$ & 0.044 \\
& $25-34$ & Ref & $1.724,2.781$ & $<0.001$ \\
& $35-44$ & 2.19 & $2.441,3.986$ & $<0.001$ \\
& $45-54$ & 3.12 & $2.715,4.616$ & $<0.001$
\end{tabular}




\begin{tabular}{|c|c|c|c|c|}
\hline & $>65$ & 5.33 & $3.938,7.213$ & $<0.001$ \\
\hline \multirow[t]{4}{*}{ Marital Status } & Married & Ref & & \\
\hline & Single & 0.75 & $0.602,0.931$ & 0.009 \\
\hline & Divorced/separated & 0.88 & $0.696,1.114$ & 0.29 \\
\hline & widowed & 1.01 & $0.785,1.295$ & 0.949 \\
\hline \multirow[t]{7}{*}{ Education } & No education & Ref & & \\
\hline & Primary & 1.15 & $0.991,1.335$ & 0.066 \\
\hline & High school & 0.97 & $0.814,1.155$ & 0.731 \\
\hline & University & 1.06 & $0.803,1.401$ & 0.68 \\
\hline & Diploma/certificate & 1.41 & $0.942,2.121$ & 0.095 \\
\hline & Monastic & 1.18 & $0.910,1.519$ & 0.215 \\
\hline & Non-formal education & 1.19 & $0.973,1.466$ & 0.09 \\
\hline \multirow[t]{10}{*}{ Occupation } & Farmer & Ref & & \\
\hline & Armed forces & 1.48 & $1.113,1.955$ & 0.007 \\
\hline & Manager & 1.95 & $1.342,2.836$ & $<0.001$ \\
\hline & Professional & 1.15 & $0.878,1.504$ & 0.312 \\
\hline & Technician & 1.33 & $1.008,1.758$ & 0.044 \\
\hline & Clerical & 1.07 & $0.726,1.587$ & 0.724 \\
\hline & Service and sales worker & 1.38 & $1.154,1.652$ & $<0.001$ \\
\hline & Craft and other trades & 1.32 & $1.007,1.722$ & 0.044 \\
\hline & Machine operator & 1.31 & $1.016,1.701$ & 0.037 \\
\hline & Monks & 1.67 & $1.049,2.649$ & 0.031 \\
\hline \multirow[t]{2}{*}{ Urban } & No & Ref & & \\
\hline & Yes & 0.93 & $0.800,1.077$ & 0.326 \\
\hline \multirow[t]{2}{*}{ Diabetes } & No & Ref & & \\
\hline & Yes & 3.46 & $2.596,4.617$ & $<0.001$ \\
\hline \multirow{2}{*}{ Ever smoked } & No & Ref & & \\
\hline & Yes & 1.12 & $0.985,1.268$ & 0.085 \\
\hline \multirow[t]{2}{*}{ Ever drank alcohol } & No & Ref & & \\
\hline & Yes & 1.04 & $0.934,1.148$ & 0.509 \\
\hline \multirow[t]{2}{*}{ Vigorous exercise } & No & Ref & & \\
\hline & Yes & 1.05 & $0.939,1.173$ & 0.398 \\
\hline \multirow[t]{4}{*}{ Vegetable serving in a week } & No & Ref & & \\
\hline & 1-3 days & 0.86 & $0.651,1.136$ & 0.288 \\
\hline & 4-5 days & 0.76 & $0.577,1.002$ & 0.052 \\
\hline & 6-7 days & 0.80 & $0.608,1.049$ & 0.106 \\
\hline \multirow[t]{4}{*}{ Worried } & No & Ref & & \\
\hline & Rarely & 1.33 & $1.156,1.532$ & $<0.001$ \\
\hline & Sometimes & 1.48 & $1.328,1.660$ & $<0.001$ \\
\hline & Always & 3.56 & $2.246,5.658$ & $<0.001$ \\
\hline
\end{tabular}

Figure 1: Proportion of hypertension by districts

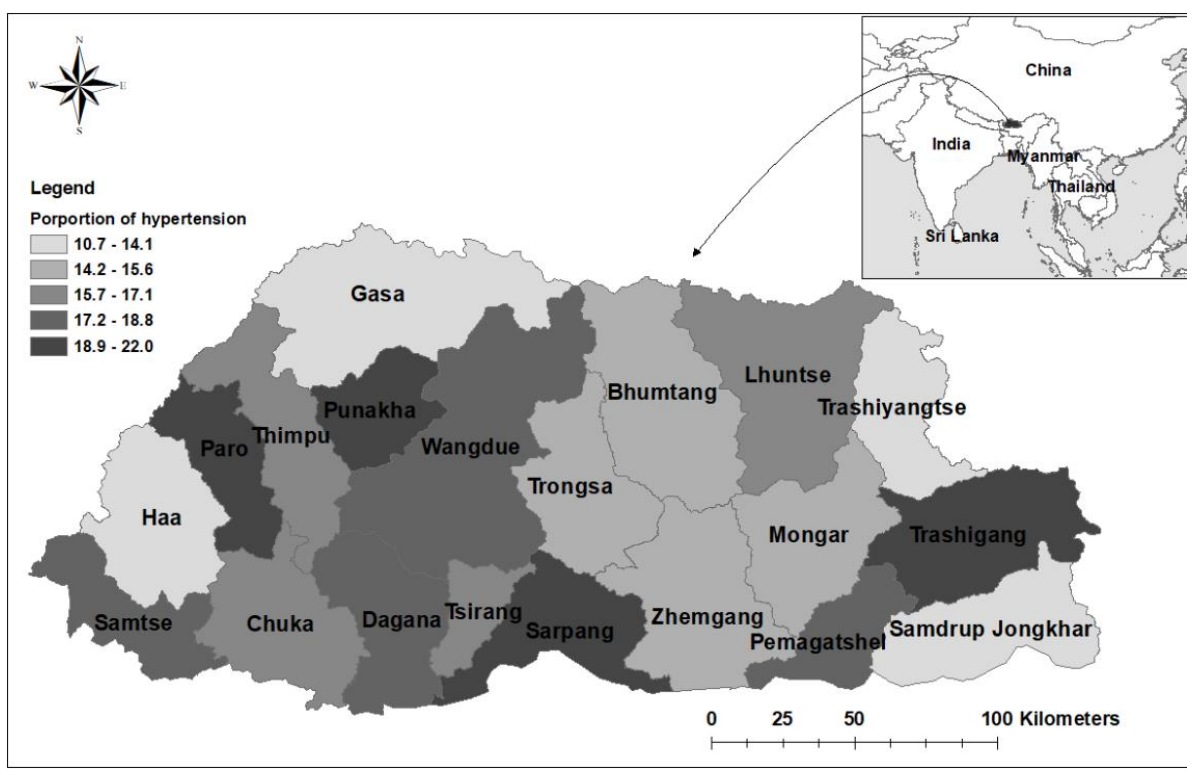


Figure 2: Forest plot adjusted odd ratios of correlates of hypertension

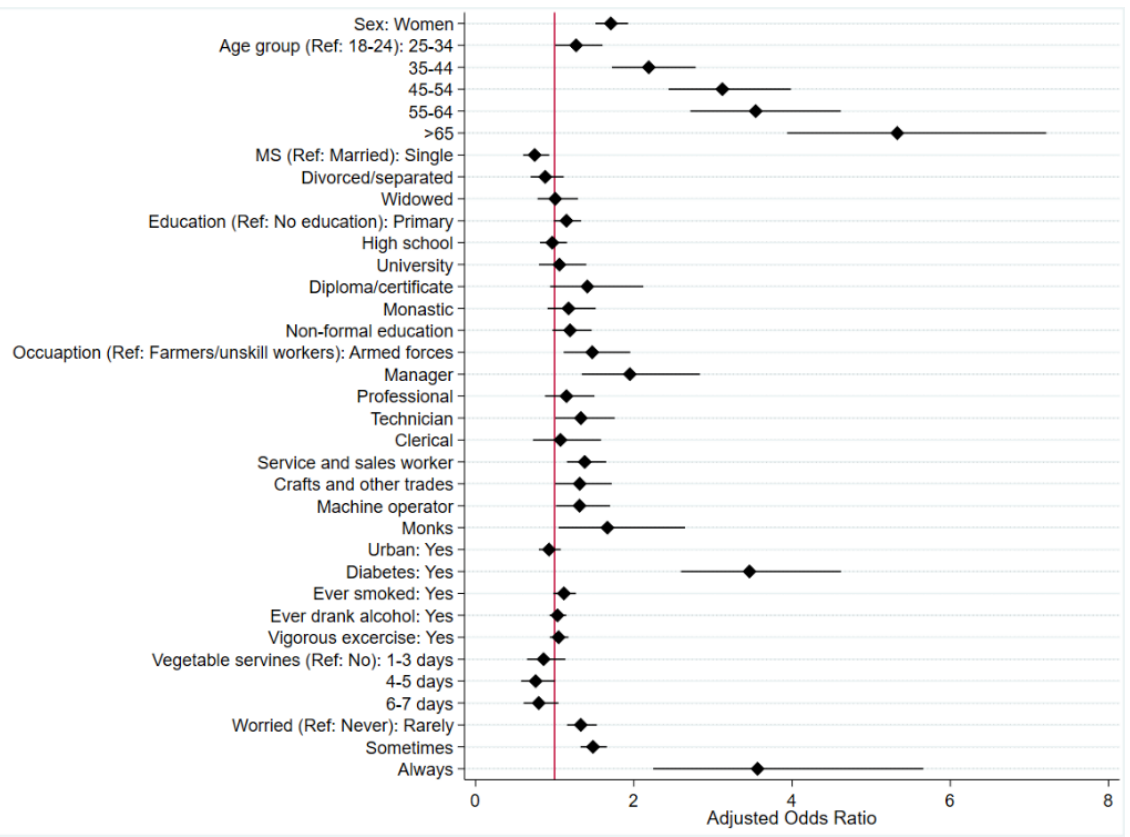

Figure 3: Probability of being hypertensive by age groups

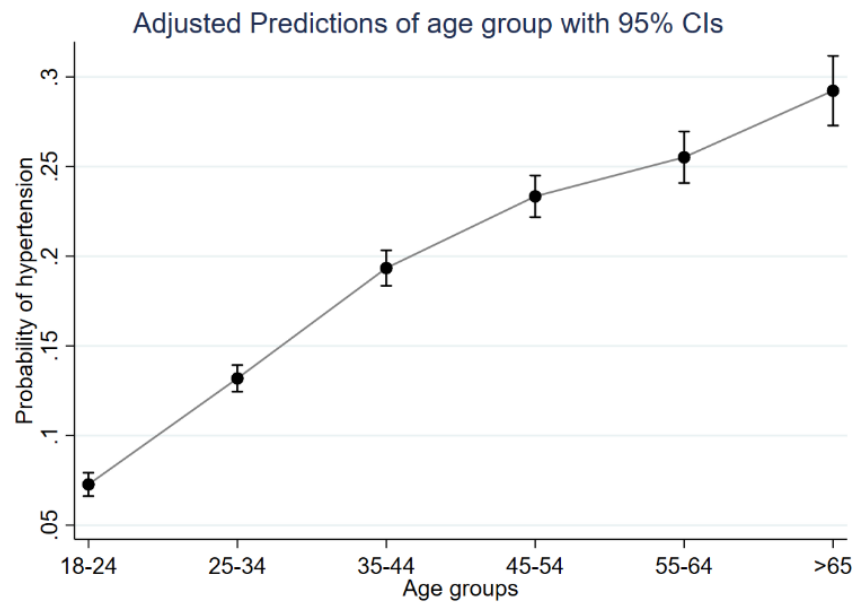

\section{Discussion}

The national prevalence of hypertension was $17.4 \%$ and the factors associated with hypertension were age, female, being a single, occupation in armed forces, managers, salespersons, technicians and monks, having diabetes and being worried.

\section{Prevalence of hypertension}

Hypertension is one of the top five non-communicable diseases in Bhutan [21]. Uncontrolled and untreated hypertension can lead to a number of complications such as heart failure, renal diseases, ischemic heart disease, pulmonary hypertension and cerebrovascular diseases including stroke [22]. Globally, it is responsible for significant disability and premature deaths [4]. Further, medical expenses in managing hypertension associated complications results are huge [2325]. Therefore, this nationally representative first epidemiological study is timely and provides much-needed evidence to policymakers of Bhutan to initiate prevention strategies for hypertension.

\section{Risk factors of hypertension}

As in other studies, women were at high risk of hypertension compared to men [26-27]. As the women reach menopause, the protection offered by oestrogen decreases thereby increasing the risk of hypertension $[28,29]$. In this study, age was an important non-modifiable risk factor for hypertension 
which is in conformity with the published literature [30]. The life expectancy of the Bhutanese population has increased from 48 years in 1975 to 69 years in 2008. This increase is due to the introduction of modern health facilities in the 1960s [31, 32]. As population ages, many pre-hypertensive populations will progress to full hypertension in the absence of appropriate preventive measures including screening and pharmacological management.

Diabetes was associated with hypertensive as in other studies [33-34]. This is due to the shared risk factors such as sedentary lifestyle and obesity [35], smoking and alcohol use, and share a common metabolic pathway [36]. Diabetes in general Bhutanese population was around $1.8 \%[17,37]$. Therefore, national preventive strategies should take a holistic approach incorporating both hypertension and diabetes.

In this study, occupations with less physical activity including monks were at risk of hypertension as compared to jobs that require physical activity. Such findings were reported in other studies from our region [38-39]. The finding that monks are at higher risk of hypertension is important because there is a large number of monks in the monasteries, and most of these monasteries do not engage in regular physical activities since appropriate facilities are not readily available. Preventive measures including regular physical activity need to be initiated, targeting these groups of people.

Hypertension was associated with poor mental health including anxiety [40,41]. The pathway between anxiety and hypertension is complex. Anxiety can increase blood pressure in the short term. For instance, a phenomenon of increased blood pressure due to the white coat effect associated anxiety is well known [42, 43]. Other pathways that increase blood pressure due to anxiety include a change in the systemic vascular resistance, sympathetic activity, plasma renin activity, the homeostasis model and blood lipids [44-45]. An indirect association between hypertension and anxiety could be related to the characteristics of anxious subjects- who may engage in an unhealthier lifestyle including increased food intake, smoking, alcohol use, and sedentary lifestyle due to stress and anxiety [46].

The risk of hypertension increased with the decreasing level of poverty in this study. This is also evident from the hypertension distribution map of Bhutan. This finding is supported by previous studies from India and Nepal [47, 48], but contrary to other published literature $[49,50]$. A plausible reason could be- increased disposable income led to increased buying capacity of fatty, energy-dense processed foods and engage in sedentary lifestyle by the wealthier people.

\section{Conclusion}

The study provides a nationally representative hypertension prevalence of $17.4 \%$. Hypertension was associated with age, being women, occupation with less physical activity, being worried and diabetes. The preventive measures both at community and health facility-based through cost-effective strategies should target these covariates.

\section{Limitation of the study:}

This study has some limitations, firstly, the cross-sectional study design cannot establish a causal relationship. Secondly, hypertension status was self-reported so respondents were subjected to probable recall bias and could not be validated and are generally underreported [51]. However, this recall bias could be minimal since they were those on medication. Thirdly, only hypertensive individuals on medication were included in the study and missed those who were asymptomatic or undiagnosed. Fourthly, self-reported behavioural habits such as vegetable consumption, smoking, alcohol use and physical activity were likely to over or underreported as a result of social desirability. Finally, the data for this data is rather old and the trends might have changed over time. Nevertheless, it is the first study on the prevalence of hypertension and its correlates in the Bhutanese population using nationally representative data. Therefore, the findings from this study can be used for national preventive strategies in Bhutan.

\section{Future scope of the study:}

Hypertension prevalence in Bhutan was high. The identified risk factors were age, being women, occupation with less physical activity, being worried and diabetes. Therefore, Bhutan should initiate regular screening programmes to detect hypertension in the older population. In addition, it is recommended to undertake prospective studies to monitor the trends of hypertension and identify the associated risk factors.

\section{What is already known on this topic?}

Previous studies on hypertension were done in the capital city Thimphu only. The risk of hypertension increased with age but other risk factors were not explored.

What this study adds:

This study presents nationally representative hypertension in adult Bhutanese. The identified risk factors in this study can be used to target preventive measures. Further, the findings can be used as a baseline to access the effectiveness of any preventive measures in the country.

\section{Authors' affiliations:}

${ }^{1}$ Research Fellow, Department of Global Health, Research School of Population Health, The Australian National University, Canberra, Australia.

${ }^{2}$ Medical Officer, Phuentsholing General Hospital, Phuentsholing, Chukha Bhutan. 
${ }^{3} \mathrm{PhD}$ Student, School of Demography, ANU College of Arts \& Social Sciences, The Australian National University, Canberra, Australia.

Author's Contribution:

${ }^{1} \mathrm{KW}$ and TJ conceptualized the analysis plan for this paper, performed the statistical analysis and drafted the manuscript.

${ }^{2}$ TJ was involved in the implementation of NHS 2012

All authors approved the final draft.

Acknowledgements:

We are grateful to the Ministry of Health, for providing us with the NHS 2012 data. We are grateful to Dr Naomi Clark for proofreading and proving valuable feedback. Lastly, we acknowledge all the study participants.

Conflict of interest:

All authors have declared that they have no conflict of interest. Source of Support:

Nil

\section{References}

1. WHO. Global status report on noncommunicable diseases 2010. 2011 [cited 2019 June 10]. Available from: https://www.who.int/nmh/publications/ncd_report2010/en/

2. WHO. Global status report on noncommunicable diseases 2014. 2011 [cited 2019 June 10]. Available from: https://www.who.int/nmh/publications/ncd-status-report-

\section{4/en/}

3. The Global brief on hypertension [cited 2019 June 5]. Available from: URL:http://www.who.int/cardiovascular diseases/publications/global_brief hypertension/en/

4. WHO. Causes of death 2008: data sources and methods. 2011 edition2011. [cited 2019 June 10]. Available from: https://www.who.int/healthinfo/global_burden_disease/cod 20 08_sources_methods.pdf

5. Messerli FH, Williams B, Ritz E. Essential hypertension. The Lancet 2007;370(9587):591-603. PMid:17707755 https://doi.org/10.1016/S0140-6736(07)61299-9

6. Kokkinos P, Pittaras A, Manolis A, et al. Exercise capacity and 24-h blood pressure in prehypertensive men and women. Am J Hypertens 2006; 19(3):251-58. PMid:17088448 https://doi.org/10.1161/01.HYP.0000250759.71323.8b

7. Coffman TM, Crowley SD. Kidney in hypertension: guyton redux. Hypertension 2008; 51(4):811-6. PMid:18332286

https://doi.org/10.1161/hypertensionaha.105.063636

8. Ha SK. Dietary salt intake and hypertension. Electrolytes Blood Press 2014; 12(1):7-18.

PMid:25061468 PMCid:PMC4105387

https://doi.org/10.5049/EBP.2014.12.1.7

9. Husain K, Ansari RA, Ferder L. Alcohol-induced hypertension: Mechanism and prevention. World J Cardiol 2014; 6(5):245-52. PMid:24891935 PMCid:PMC4038773 https://doi.org/10.4330/wjc.v6.i5.245

10. Lloyd-Sherlock P, Beard J, Minicuci N, Ebrahim S, Chatterji S. Hypertension among older adults in low- and middle-income countries: prevalence, awareness and control. Int J Epidemiol 2014; 43(1):116-28.

PMid:24505082 PMCid:PMC3937973

https://doi.org/10.1093/ije/dyt215

11. Primatesta P, Falaschetti E, Gupta S, Marmot MG, Poulter NR. Association between smoking and blood pressure: Evidence from the health survey for England. Hypertension 2001; 37(2):187-93. PMid:11230269

https://doi.org/10.1161/01.HYP.37.2.187

12. Popkin BM, Hortson S, Kim S. The nutritional transition and diet-related chronic diseases in Asia: Implications for prevention. (Food Consumption and Nutrition Division IFPRI ed., vol. FCND DISCUSSION PAPER NO. 105. Washington, D.C.2001. Available from: https://www.ifpri.org/publication/ nutritional-transition-and-diet-related-chronic-diseases-asia 13. Popkin BM, Adair LS, Ng SW. Now and then: The Global Nutrition Transition: The Pandemic of Obesity in Developing Countries. Nutrition Reviews 2012; 70(1):3-21.

PMid:22221213 PMCid:PMC3257829

https://doi.org/10.1111/j.1753-4887.2011.00456.x

14. Turin TC, Shahana N, Wangchuk LZ, et al. Burden of Cardio- and Cerebro-vascular Diseases and the Conventional Risk Factors in South Asian Population. Global Heart 2013; 8(2):121-30. PMid:25690377

https://doi.org/10.1016/j.gheart.2012.01.001

15. Giri BR, Sharma KP, Chapagai RN, Palzom D. Diabetes and hypertension in urban bhutanese men and women. Indian $\mathrm{J}$ Community Med 2013; 38(3):138-43.

PMid:24019598 PMCid:PMC3760321

https://doi.org/10.4103/0970-0218.116349

16. NSB. Bhutan Multidimensional Poverty Index 2012. 2014 [cited 2019 June 15]. Available at: http://www.nsb.gov.bt/publication/files/pub0111571bt.pdf 17. MoH. National Health Survey 2012 report. 2012 [cited 2019 June 15]. Available from: http://www.health.gov.bt/wpcontent/uploads/moh-files/nationalHealthSurvey2012.pdf

18. Kingue S, Ngoe CN, Menanga AP, et al. Prevalence and Risk Factors of Hypertension in Urban Areas of Cameroon: A Nationwide Population-Based Cross-Sectional Study. J Clin Hypertens (Greenwich) 2015; 17(10):819-24. PMid:26140673 https://doi.org/10.1111/jch.12604

19. Cois A, Ehrlich R. Analysing the socioeconomic determinants of hypertension in South Africa: a structural equation modelling approach. BMC Public Health 2014; 14:414. PMid: 24885860 PMCid: PMC4021547

https://doi.org/10.1186/1471-2458-14-414 
20. Saeed KM, Rasooly MH, Brown NJ. Prevalence and predictors of adult hypertension in Kabul, Afghanistan. BMC Public Health 2014; 14:386. PMid: 24754870 PMCid:PMC4047782

https://doi.org/10.1186/1471-2458-14-386

21. MoH: Annual Health Bulletin 2016. 2017 [cited 2019 June

16]. Available from: http://www.health.gov.lk/moh_final/ english/public/elfinder/files/publications/AHB/2017/AHB_20 16.pdf

22. Lionakis N, Mendrinos D, Sanidas E, Favatas G, Georgopoulou M. Hypertension in the elderly. World J Cardiol 2012; 4(5):135-47. PMid:18174773

https://doi.org/10.1111/j.1524-6175.2007.07202.x

23. Jin CN, Yu CM, Sun JP, et al. The healthcare burden of hypertension in Asia. Heart Asia 2013; 5:238-43.

PMid: 27326143 PMCid:PMC4832751

https://doi.org/10.1136/heartasia-2013-010408

24. Nanditha A, Ma RC, Ramachandran A, et al. Diabetes in Asia and the Pacific: Implications for the Global Epidemic. Diabetes Care 2016; 39(3):472-85. PMid:26908931

https://doi.org/10.2337/dc15-1536

25. Mohan V, Seedat YK, Pradeepa R. The rising burden of diabetes and hypertension in southeast asian and african regions: need for effective strategies for prevention and control in primary health care settings. Int J Hypertens 2013; 2013:409083. PMid:23573413 PMCid:PMC3612479

https://doi.org/10.1155/2013/409083

26. Gurven M, Blackwell AD, Rodriguez DE, Stieglitz J, Kaplan H. Does blood pressure inevitably rise with age?: longitudinal evidence among forager-horticulturalists. Hypertension 2012; 60(1):25-33.

PMid: 22700319 PMCid:PMC3392307

https://doi.org/10.1161/HYPERTENSIONAHA.111.189100

27. Bansal SK, Saxena V, Kandpal SD, Gray WK, Walker RW, Goel D. The prevalence of hypertension and hypertension risk factors in a rural Indian community: A prospective doorto-door study. J Cardiovasc Dis Res 2012; 3(2):117-23.

PMid:22629029 PMCid:PMC3354454

https://doi.org/10.4103/0975-3583.95365

28. Gudmundsdottir H, Hoieggen A, Stenehjem A, Waldum B,

Os I. Hypertension in women: latest findings and clinical implications. Ther Adv Chronic Dis 2012; 3(3):137-46.

PMid:23251774 PMCid: PMC3513905

https://doi.org/10.1177/2040622312438935

29. Ahmad A, Oparil S. Hypertension in Women: Recent Advances and Lingering Questions. Hypertension 2017; 70(1):19-26. PMid:28483918

https://doi.org/10.1161/HYPERTENSIONAHA.117.08317

30. Sarki AM, Nduka CU, Stranges S, Kandala NB, Uthman

OA. Prevalence of Hypertension in Low- and Middle-Income
Countries: A Systematic Review and Meta-Analysis. Medicine (Baltimore) 2015; 94(50):e1959. PMid:26683910 PMCid:PMC5058882

https://doi.org/10.1097/MD.0000000000001959

31. MoH. Annual Health Bulletin 2000. 2000 [cited 2019 June

17]. Available from: http://www.health.gov.bt/wp-content/ uploads/ftps/annual-health-bulletins/Annual\%20Health $\% 20$

Bulletin-2000.pdf

32. MoH. Annual Health Bulletin 2016. 2016 [cited 2019 June

17. Available from: http://www.health.gov.bt/wpcontent/uploads/ftps/annual-health-bulletins/Annual\%20

Health \% 20Bulletin-2016.pdf

33. Dhungana RR, Pandey AR, Bista B, Joshi S, Devkota S. Prevalence and Associated Factors of Hypertension: A Community-Based Cross-Sectional Study in Municipalities of Kathmandu, Nepal. Int J Hypertens 2016; 2016:1656938.

PMid:27293880 PMCid:PMC4880705

https://doi.org/10.1155/2016/1656938

34. Williams B. Treating hypertension in patients with diabetes: When to start and how low to go? JAMA 2015; 313(6):573-4. PMid:25668260

https://doi.org/10.1001/jama.2015.89

35. Haslam DW, James WP. Obesity. Lancet 2005; 366(9492):1197-1209. PMid:16198769

https://doi.org/10.1016/S0140-6736(05)67483-1

36. Cheung BM, Li C. Diabetes and Hypertension: Is There a Common Metabolic Pathway? Curr Atheroscler Rep 2012; 14(14):160-6. PMid: 22281657 PMCid:PMC3314178

https://doi.org/10.1007/s11883-012-0227-2

37. Wangdi K, Jamtsho T. Risk factors for self-reported diabetes among Bhutanese adults: A nationally representative survey data analysis. PLoS One 2018; 13(11):e0206034.

PMid: 30439962 PMCid:PMC6237308

https://doi.org/10.1371/journal.pone.0206034

38. Singh RB, Suh IL, Singh VP, et al. Hypertension and stroke in Asia: prevalence, control and strategies in developing countries for prevention. J Hum Hypertens 2000; 14(1014):749-63. PMid:11095165

https://doi.org/10.1038/sj.jhh.1001057

39. Lane K, Sunderarajan S, Vanzan H, et al. Urbanization is an independent predictor of blood pressure in a South Asian population. Journal of the American College of Cardiology 2014; 63(12).

40. Bacon SL, Campbell TS, Arsenault A, Lavoie KL. The impact of mood and anxiety disorders on incident hypertension at one year. Int J Hypertens 2014; 2014:953094.

PMid:24672713 PMCid:PMC3941592

https://doi.org/10.1155/2014/953094

41. Pan Y, Cai W, Cheng Q, Dong W, An T, Yan J. Association between anxiety and hypertension: a systematic 
review and meta-analysis of epidemiological studies. Neuropsychiatr Dis Treat 2015; 11:1121-30.

PMid:25960656 PMCid:PMC4411016

https://doi.org/10.2147/NDT.S77710

42. Leventhal H, Contrada RJ, Leventhal EA. Lessons from white coat hypertension: comment on Spruill et al. "The impact of perceived hypertension status on anxiety and the white coat effect". Ann Behav Med 2007, 34(1):10-3.

PMid:17688392

https://doi.org/10.1007/bf02879916

43. Spruill TM, Pickering TG, Schwartz JE, et al. The impact of perceived hypertension status on anxiety and the white coat effect. Ann Behav Med 2007; 34(1):1-9. PMid:17688391

https://doi.org/10.1007/bf02879915

44. Lambert E, Dawood T, Straznicky N, et al. Association between the sympathetic firing pattern and anxiety level in patients with the metabolic syndrome and elevated blood pressure. J Hypertens 2010; 28(3):543-50. PMid: 20139772

https://doi.org/10.1097/HJH.0b013e3283350ea4

45. Bajko Z, Szekeres CC, Kovacs KR, et al. Anxiety, depression and autonomic nervous system dysfunction in hypertension. J Neurol Sci 2012; 317(1-2):112-6.

PMid:22425019

https://doi.org/10.1016/j.jns.2012.02.014

46. Bonnet F, Irving K, Terra JL, Nony P, Berthezene F, Moulin P. Anxiety and depression are associated with unhealthy lifestyle in patients at risk of cardiovascular disease. Atherosclerosis 2005; 178(2):339-44. PMid:15694943

https://doi.org/10.1016/j.atherosclerosis.2004.08.035

47. Hasan M, Sutradhar I, Akter T, et al. Prevalence and determinants of hypertension among adult population in Nepal: Data from Nepal Demographic and Health Survey 2016. PLoS One 2018; 13(5):e0198028.

PMid:29852006 PMCid:PMC5978874

https://doi.org/10.1371/journal.pone.0198028

48. Geldsetzer P, Manne-Goehler J, Theilmann M, et al. Diabetes and Hypertension in India: A Nationally Representative Study of 1.3 Million Adults. JAMA Intern Med 2018; 178(3):363-72. PMid:29379964 PMCid:PMC5885928

https://doi.org/10.1001/jamainternmed.2017.8094

49. Seedat YK. Impact of poverty on hypertension and cardiovascular disease in sub-Saharan Africa. Cardiovasc J Afr 2007, 18(5):316-20. PMidD:17957321 PMCed:PMC3975541

50. Antignac M, Diop IB, Macquart de Terline D, et al. Socioeconomic Status and Hypertension Control in SubSaharan Africa: The Multination EIGHT Study (Evaluation of Hypertension in Sub-Saharan Africa). Hypertension 2018; 71(4):577-84. PMid:29378852

https://doi.org/10.1161/HYPERTENSIONAHA.117.10512
51. Goldman N, Lin IF, Weinstein M, Lin YH: Evaluating the quality of self-reports of hypertension and diabetes. J Clin Epidemiol 2003; 56(2):148-54. PMid: 12654409

https://doi.org/10.1016/s0895-4356(02)00580-2 